\section{A technique for measuring thermoregulatory behavior in the fish}

\author{
LAWRENCE H. FRANK \\ Western Washington State College, Bellingham, Washington 98225
}

Apparatus and procedure are described for studying thermoregulatory behavior in fish. Results obtained with rainbow trout suggest that the described apparatus has several advantages over previously utilized devices.

Past experiments on thermoregulatory behavior of fish have utilized apparatus in which manipulation of an operandum initiates a decrease in water temperature (Rosin \& Mayer, 1961). Typically, fish have been placed within a tank, and the water temperature gradually raised to a near-lethal level by heating rods. Through successive approximations, the fish have been shaped to barpress for small decreases $\left(0.30^{\circ}-0.60^{\circ} \mathrm{C}\right)$ in water temperature. A procedure such as this has three basic limitations: the temperature range that may be employed for reinforcement is small; the rate of thermal change is not constant; and the method of training is long (about $2 \mathrm{~h})$ and laborious. The apparatus described in this paper provides several advantages over previously utilized devices.

The apparatus is schematized in Fig. 1 and consists of a watertight gray plywood chamber $30 \mathrm{~cm}$ long, $15 \mathrm{~cm}$ wide, and $20 \mathrm{~cm}$ high. A gray plywood partition divides the chamber into two equal compartments. A series of 6- $\mathrm{mm}$ holes performates the partition, permitting an easy flow of water. A $5 \mathrm{~cm}$ aperture extending the width of the partition, $6.25 \mathrm{~cm}$ from thebottom, permits free movement of

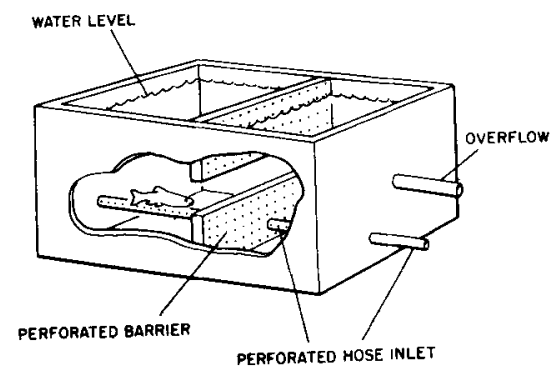

Fig. 1. A schematic of the experimental chamber. the $S$ from one compartment to the other. Infrared photoelectric cells are mounted parallel to the aperture outside the chamber. Thus, if movement is made in either direction through the aperture, the photoelectric beam will be disrupted, activating an electronic counter and a water solenoid valve.

A $110-\mathrm{V}$ ac double solenoid water valve (Dole, No. 33) is mounted $60 \mathrm{~cm}$ from the experimental chamber on an independent stand. A perforated rubber hose, $1.25 \mathrm{~cm}$ in diam, is attached to the solenoid and transverses the bottom of the chamber. A flow of either hot $\left(29^{\circ} \mathrm{C}\right)$ or cold $\left(12^{\circ} \mathrm{C}\right)$ water can be directed through the solenoid and hose into the chamber. Overflows positioned in each end of the chamber maintained a water level of $17.5 \mathrm{~cm}$.

\section{Supporting Data}

Twelve rainbow trout (Salmo gairdneri) were divided randomly into two groups (experimental and yoked control conditions) of six Ss each.

At the beginning of each session, one $S$ was placed within a $29^{\circ} \mathrm{C}$ environment (the lethal temperature for Salmo gairdneri is approximately $\left.31^{\circ} \mathrm{C}\right)$. A steady flow of hot water (3 liters/min) was initiated which continued until the $\mathrm{S}$ swam through the opening in the partition, then a 10-sec flow of cold water occurred causing a transient drop of $2^{\circ} \mathrm{C}$ in the environmental temperature. Immediately after the cold water stopped, a steady flow of hot water occurred and continued until the $S$ made another response. The experimental sessions were $20 \mathrm{~min}$ in length, one per day, for 5 days.

The mean number of responses for Days $1,2,3,4$, and 5 for control Ss were $26.8,29.1,13.0,22.5$, and 10.2, respectively, and for the experimental Ss, 163.2, 184.8, 266.0, 263.5, and 276.3 , respectively. The experimental Ss responded significantly higher on the initial and all subsequent days than did the controls. The most prominent feature of the data was that the rate of response for the experimental Ss increased over days, depicting thermoregulation, while the frequency of response for the control Ss was variable.

\section{DISCUSSION AND CONCLUSIONS}

The most salient feature of the present apparatus is its utilization of a double solenoid water valve (cost, approximately \$6). Two sources of temperature-regulated water may be attached to the solenoid. The water valve operates in an either/or fashion, permitting one of the temperature-selected water sources (A) to flow while it prevents the second water source (B) from entering the chamber. The solenoid can be thrown electronically to shut off the flow of water $A$, while at the same time it initiates the flow of water B (time constant for closure approximately $0.10 \mathrm{sec}$ ). The actual speed of environmental temperature change in the chamber is regulated by the respective pressure of each water source, i.e., the higher the pressure, the faster the change. It should also be noted that the temperature change is evenly distributed throughout the chamber's horizontal plane due to the even inflow of water. A further advantage of the present apparatus is that the continuous flow of water through the chamber provides natural aeration, thus eliminating the necessity for an artificial mechanism.

By use of an electronic clock and relays, the apparatus is easily modified to study behavior under different schedules of reinforcement, as well as other aspects of thermal behavior. Sidman avoidance in fish, for example (with temperature acting as the unconditioned stimulus), can be programmed readily. Similarly, Frank and Meyer (1971) have modified the apparatus to investigate the activity of fish as a function of acclimation and thermal environment.

\section{REFERENCES}

FRANK, L. H., \& MEYER, M. E. Activity in rainbow trout (Salmo gairdneri) as function of acclimation and thermal environment. Psychonomic Science, $1971,23,377-378$.

ROZIN, P. N., \& MAYER, J. Thermal reinforcement and thermoregulatory behavior in the goldfish, Carassius auratus. Science, 1961, 134, 942-943. 